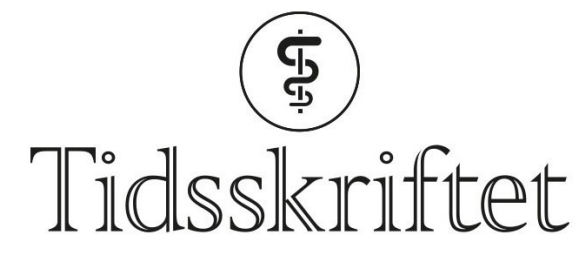

DEN NORSKE LEGEFORENING

\title{
Språkspalten gjennom 30 år
}

SPRÅKSPALTEN

\section{ERLEND HEM}

E-post: erlend.hem@medisin.uio.no

Erlend Hem er instituttsjef ved Legeforskningsinstituttet og professor ved Universitetet i Oslo. Han har hatt ulike redaktørstillinger i Tidsskriftet gjennom 20 år og var redaktør for språkspalten i perioden 2015-20.

\section{PETTER GJERSVIK}

Petter Gjersvik er professor ved Universitetet i Oslo, medisinsk redaktør i Tidsskriftet og fra oktober 2020 redaktør for språkspalten.

Tidsskriftets språkspalte er til for å styrke norsk medisinsk fagspråk.

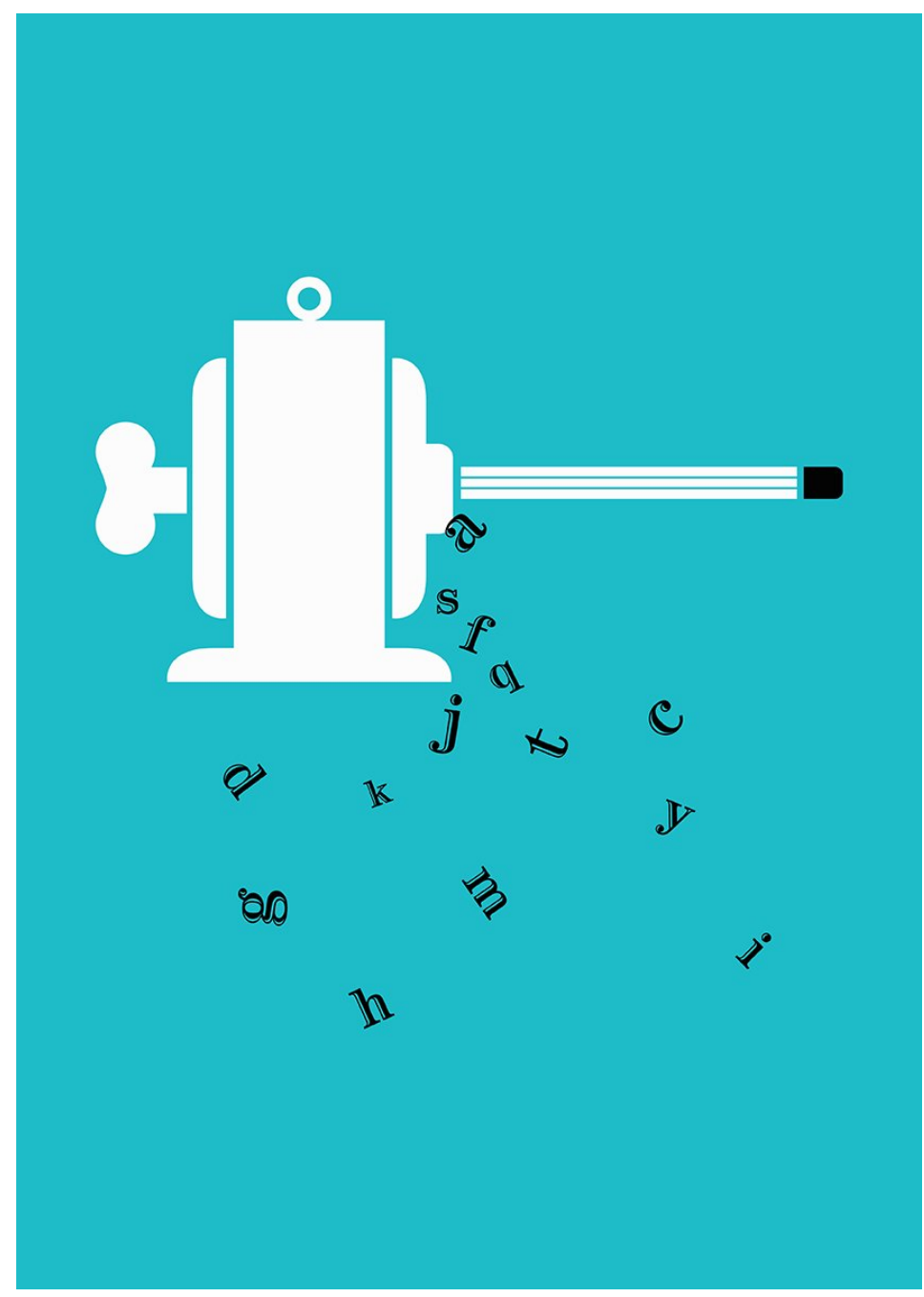


Godt norsk fagspråk er viktig for å praktisere medisin, drive helseinformasjon og kommunisere med pasienter, pårørende og publikum. Sterk språklig bevissthet styrker tanken. Medisinsk språk har vært diskutert i Tidsskriftet i alle år, men det var først i 1990 at redaktør Magne Nylenna startet en egen spalte for medisinsk fagspråk (1).

Hva er så status for språkspalten etter 30 år? Vi kan fastslå at aktiviteten har vært gledelig stor $(2,3)$. De siste ti årene har Tidsskriftet publisert 228 språkspalteartikler, 108 av dem i perioden 2016-20.

\section{Fra engelsk til norsk}

Mange er skeptiske til å finne norske avløserord for engelske faguttrykk. Ofte hører vi argumenter som «alle i fagmiljøet bruker det engelske ordet» og «mange ord på engelsk lar seg ikke oversette til norsk». Vår erfaring er oftere det motsatte. Dersom man finner fram til gode norske fagord, og kommer tidlig til, er sjansene gode for at avløserordet blir tatt i bruk. Språkspalten har her en viktig oppgave.

Mange innlegg i språkspalten har nettopp handlet om å finne gode norske ord og uttrykk, slik som infeksjon oppstått utenfor sykehus (community-acquired infection), forhåndssamtaler (advance care planning) og avmedisinering (deprescribing).

\section{Gamle og nye ord}

Mange forfattere har drøftet ord som kan oppfattes som belastede, slik som skamben og tvillingabort, glemte ord som lipotymi og feberkrise, moteord som robust og paradigmeskifte, problematiske ord som prospektiv og retrospektiv, aktuelle ord som pandemi og karantene og ikke minst nye ord som chemsex, gittercelle, tarmflorabehandling, helsekompetanse og presisjonsmedisin.

Noen ganger forsøker spalten å bidra til språklig utvikling, for eksempel gjennom å erstatte antiepileptika med anfallsforebyggende legemidler, føflekkreft med melanom og fosterreduksjon med fosterantallsreduksjon. Og hva er riktig skrivemåte: Downs syndrom eller Down syndrom? Donders' metode eller Donders metode? Antidepressiver eller antidepressiva?

\section{Tverrfaglig samarbeid}

Statistiske termer står sentralt i forskning og klinisk praksis. I 2017 startet Tidsskriftet en spalte om medisinsk statistikk: Medisin og tall. Denne har ført til et godt samarbeid om statistiske fagtermer, slik som kasus-kontroll-studie framfor pasient-kontroll-studie og krysstabell framfor kontingenstabell.

I 2015 ble Gruppe for norsk medisinsk fagspråk etablert (3). Den består av elleve medlemmer med bakgrunn fra medisin, andre helsefag og språkfag. Gruppen arbeider for å styrke bruken av norsk i faglige sammenhenger og samarbeider med språkgrupper med tilknytning til Språkrådet, i første rekke Termgruppe for celle- og molekylcrbiologi.

\section{$\emptyset$ kt språklig bevissthet}

Språkspalten ønsker å ta opp større og prinsipielt viktige saker for språklig praksis innen medisin og forskning, ikke minst påvirkningen fra engelsk. Våren 2020 kom to viktige dokumenter om norsk fagspråk: en offentlig utredning om ny universitets- og høyskolelov og et forslag til landets første språklov. I proposisjonen sto det tydelig: «Ein lege må sjølvsagt kunne den medisinske fagterminologien og halde seg oppdatert på faget i internasjonale tidsskrift. Ho eller han må likevel kunne snakke om helse og sjukdom på norsk med den norske pasienten slik at pasienten blir opplyst og kjenner seg trygg» (4). Spørsmålet er hva myndighetene har tenkt å gjøre for å styrke norsk fagspråk. Til nå har det vært lite støtte fra universitetsmiljøene:Ved Det medisinske fakultet i Oslo er det nylig 
innført et krav om bruk av engelsk ved doktorgradsdisputaser (5). Et ønske om internasjonalisering av norsk medisinsk forskning må ikke svekke vår språklige bevissthet og vår forpliktelse til å formidle medisinsk kunnskap på en forståelig måte (6).

Språkspalten har en viktig oppgave i å styrke et godt norsk medisinsk fagspråk og å øke den språklige bevisstheten blant norske leger og forskere. Vi mottar gjerne bidrag om smått og stort.

LITTERATUR:

1. Nylenna M. Språkspalten. Tidsskr Nor Lægeforen 1990; 110: 1871.

2. Hem E. Språkspalten er 20 år! Tidsskr Nor Legeforen 2010; 130: 1373. [CrossRef]

3. Hem E. Språkspalten er 25 år. Tidsskr Nor Legeforen 2015; 135: 2197. [PubMed][CrossRef]

4. Språk i forsking og høgare utdanning. I: Prop. 108 L (2019-2020) - Lov om språk (språklova).

Proposisjon 12.5.2020. Kulturdepartementet.

https://www.regjeringen.no/no/dokumenter/prop.-108-1-20192020/id2701451/ Lest 20.10.2020.

5. Nylenna M. På vei mot en ny latintid? Tidsskr Nor Legeforen 2020; 140. doi: 10.4045/tidsskr.20.0026. [CrossRef]

6. Hem E, Knævelsrud H, Bustad HJ. Norsk fagspråk må styrkes. Klassekampen 4.8.2020: 20. https://klassekampen.no/utgave/2020-o8-o4/debatt-norsk-fagsprak-ma-styrkes Lest 20.10.2020.

Publisert: 11. januar 2021. Tidsskr Nor Legeforen. DOI: 10.4045/tidsskr.20.0719

(C) Tidsskrift for Den norske legeforening 2020. Lastet ned fra tidsskriftet.no 